\title{
Efficacy of Copper and New Bactericides for Managing Olive Knot in California
}

\author{
K. A. Nguyen, H. Förster, and J. E. Adaskaveg, ${ }^{\dagger}$ Department of Microbiology and Plant Pathology, University of California, Riverside 92521
}

\begin{abstract}
Baseline sensitivities were established for kasugamycin and oxytetracycline for 147 strains of Pseudomonas savastanoi pv. savastanoi collected from olive knots throughout California. Minimum inhibitory concentrations for $\geq 95 \%$ growth inhibition ranged from 1.86 to 11.52 and 0.13 to $0.40 \mu \mathrm{g} / \mathrm{ml}$ for kasugamycin and oxytetracycline, respectively. In copper sensitivity evaluations, $95.3 \%$ of the strains collected grew at concentrations of metallic copper equivalent (MCE) of $<20 \mu \mathrm{g} / \mathrm{ml}, 2.7 \%$ grew at MCE between 20 and $30 \mu \mathrm{g} / \mathrm{ml}$ (moderately sensitive), and $2 \%$ grew at MCE of $150 \mu \mathrm{g} / \mathrm{ml}$ (resistant). Copper resistance was never reported previously in the olive knot pathogen, and pathogenicity studies confirmed a high virulence of the copper-resistant strains. In comparative field studies, kasugamycin at $200 \mu \mathrm{g} / \mathrm{ml}$ performed equally to the standard copper hydroxide treatment (MCE of $1,260 \mu \mathrm{g} / \mathrm{ml}$ ) for reducing

knot development on lateral wounds of Arbequina and Manzanillo olive inoculated with a copper-sensitive strain and was better than copper using a highly copper-resistant strain. Oxytetracycline at $200 \mu \mathrm{g} / \mathrm{ml}$ was not as effective as copper or kasugamycin but significantly reduced the disease as compared with the untreated control. Field studies on application timings of copper, kasugamycin, and copper-kasugamycin mixtures to inoculated wounds indicated that treatments within $24 \mathrm{~h}$ of inoculation resulted in higher disease control than applications at later times. In greenhouse trials, copper or copper-kasugamycin applied to wounds 7 days before inoculation persisted and reduced knot incidence by $>50 \%$. Our findings indicate that kasugamycin is an effective bactericide for controlling olive knot and that the time of any bactericide application after inoculation is critical in managing the disease.
\end{abstract}

Pseudomonas savastanoi pv. savastanoi (Gardan et al. 1992) is the causal agent of olive knot, an economically important disease of olive (Olea europaea L.) worldwide (Young 2004). The bacterium can survive on its host as an epiphyte (Ercolani 1978) and is an opportunistic pathogen that relies on wounds as entry points to incite disease (Wilson 1935). Wounds may be naturally created by environmental factors such as severe weather that cause injuries to trees (e.g., frost damage, hail, and windstorms). Additionally, spring leaf drop and foliar diseases such as peacock spot create leaf scar wounds that are highly susceptible to infection by the pathogen. Changes in California olive production practices that are adapting the Spanish high-density and super-high-density planting systems with automated hedging and mechanical harvesting (Tous et al. 2010; Vossen 2007) have increased the risk of disease spread by providing more wounds to the pathogen. After invading susceptible tissue, the bacterium produces and releases indole-acetic acid (Comai and Kosuge 1980,1982) and cytokinins (Surico et al. 1985). These phytohormones stimulate hyperplasia and hypertrophy of the surrounding olive tissue, leading to the development of outgrowths known as knots or galls (Surico et al. 1985) that can be long lived and harbor high concentrations of bacteria. The majority of knots form on twigs, trunks, and branches but leaves, petioles, peduncles, racemes, and fruit occasionally also become infected (Wilson 1935). In addition to knots, the disease may cause tree defoliation, branch dieback, and reduced tree vigor, which ultimately lowers yield, and it has also been implicated in reducing fruit quality (Schroth et al. 1968, 1973). Knots serve as the primary inoculum source, and high concentrations of $P$. savastanoi pv. savastanoi are often recovered from the surfaces of wetted knots (Horne et al. 1912; Wilson 1935). The bacterium is disseminated by splashing water, wind, insects, birds, and human activity. Infections can be initiated year-round when conditions are favorable, and are not limited by temperatures as low as $-5^{\circ} \mathrm{C}(\mathrm{K}$. A. Nguyen unpublished), although knots will only begin to develop when trees are actively growing during the spring, summer, and fall seasons.

The most effective strategy for managing olive knot is prevention by using clean nursery stock and growing olive trees in areas less

${ }^{\dagger}$ Corresponding author: J. E. Adaskaveg; E-mail: jim.adaskaveg@ucr.edu

Funding: This work was supported with funding from the California Olive Board and the California Olive Oil Council.

Accepted for publication 24 November 2017.

@ 2018 The American Phytopathological Society conducive for disease development such as locations with minimal rainfall and freezing events (Wilson 1935). Once olive knot becomes established, eradication is often not feasible, and the disease must be controlled to minimize further spread. Disease management may include pruning and removal of infected plant material from the orchard under dry conditions. Field equipment (i.e., pruners and harvesters) should be properly sanitized to reduce the risk of transmitting the pathogen from diseased to healthy plants through contaminated surfaces (Nguyen et al. 2017).

Another important strategy for disease control is the use of properly timed applications of chemical protectants. Painting knots with cresol- and xylenol-based compounds (e.g., Gallex) can be an effective practice. However, this is not feasible on a commercial scale because individual knots have to be treated, which requires excessive labor. Furthermore, the compounds are toxic to leaves and cannot be applied as foliar sprays (Schroth and Hildebrand 1968; Sibbett and Ferguson 2005). Copper is the best foliar treatment currently available for the control of olive knot. It is typically applied twice a year, once in the fall after harvest and again in the spring following natural leaf drop (Teviotdale and Krueger 2004). On other crops, the excessive use and dependence on copper as the only means for controlling phytopathogenic bacteria have led to the development of copper resistance in bacterial pathogens and in a reduction of its effectiveness (Adaskaveg and Hine 1985; Andersen et al. 1991; Marco and Stall 1983). The sole and repeated use of various copper formulations for the control of olive knot in California since the early 1900s (Horne et al. 1912; Wilson 1935) possibly has resulted in the selection of resistance in the pathogen population. Teviotdale and Krueger (1998) evaluated a California $P$. savastanoi pv. savastanoi population for copper resistance but only found copper-resistant strains that were not pathogenic on olive. Some California olive growers have reported reduced efficacy of copper, and resistance in the pathogen populations has been considered a possible cause. Other factors such as inappropriate timing of applications in respect to wounding and infection events, however, are alternative explanations.

With limited treatment options available for controlling olive knot, we evaluated kasugamycin and oxytetracycline as possible new treatments for the management of the disease. Integration of new modes of action to currently available treatments would reduce the risk of resistance development in the pathogen population and help to prolong the effective use life of these bactericides. Kasugamycin is produced by the grampositive bacterium Streptomyces kasugaensis, and was discovered in the 1960s (Umezawa et al. 1965). Kasugamycin is an aminoglycoside 
that inhibits bacterial protein synthesis by interfering with the formation of the 30S initiation complex during translation (Okuyama et al. 1971; Tanaka et al. 1966). Kasugamycin is active against many important genera of plant-pathogenic bacteria, including Erwinia, Xanthomonas, and Pseudomonas (J. E. Adaskaveg, unpublished). We previously demonstrated the effectiveness of kasugamycin against fire blight of pome fruits caused by Erwinia amylovora, and the bactericide was subsequently registered for use on these crops (Adaskaveg et al. 2011). Unlike oxytetracycline, kasugamycin is not used in human and animal medicine (Adaskaveg et al. 2011; McGhee and Sundin 2011) and is not considered to be toxic to mammals or persistent in the environment (Copping and Duke 2007; Lu et al. 2012). The tetracycline compound oxytetracycline is registered as a foliar treatment against bacterial diseases on certain stone and pome fruit and as an injection treatment for lethal yellows of palm and elm phloem necrosis that are both caused by phytoplasmas.

The objectives of this study were to collect strains of $P$. savastanoi pv. savastanoi from California olive-growing regions, characterize their sensitivity to copper, and establish baseline sensitivities to kasugamycin and oxytetracycline. The efficacy of kasugamycin, oxytetracycline, and copper hydroxide was evaluated in comparative field trials. Application timing and persistence studies were conducted in greenhouse or field studies to assess pre- and postinfection activity of the treatments and to determine optimum use strategies for managing olive knot.

\section{Materials and Methods}

Isolation of $P$. savastanoi pv. savastanoi strains from diseased plant samples and culturing of the pathogen. Olive twigs and branches with knots were collected between 2011 and 2015 from commercial oil and table olive orchards in major production areas of California (Butte, Colusa, Glenn, Tehama, Tulare, and Yuba Counties) (Table 1). Internal knot tissue was excised with a sterile scalpel and placed into microcentrifuge tubes, $600 \mu \mathrm{l}$ of sterile deionized water was added, and tubes were vigorously shaken for $5 \mathrm{~min}$ on a vortex shaker. The suspension was streaked onto PVF-1 agar (Surico and Lavermicocca 1989). Plates were incubated for 3 days at $25^{\circ} \mathrm{C}$ before visualization under long-wavelength $(365 \mathrm{~nm})$ ultraviolet light (Benchtop 2 UV transilluminator; UVP, LLC, Upland, CA). Fluorescent single colonies were transferred onto King's Medium B (KMB) (King et al. 1954). Molecular identification was done by polymerase chain reaction (PCR) with species-specific primers IAALF and IAALR (Penyalver et al. 2000) targeting the iaaL gene. Isolates positively identified as $P$. savastanoi pv. savastanoi were stored in $15 \%$ glycerol at $-80^{\circ} \mathrm{C}$.

Laboratory evaluation of copper sensitivity of $P$. savastanoi pv. savastanoi strains. Evaluation of copper sensitivity was performed using an agar dilution-plate assay. Molten casitone-yeast extract-glycerol agar (Zevenhuizen et al. 1979) was amended with cupric sulfate (Mallinckrodt, St. Louis) to final concentrations of metallic copper equivalents (MCE) of 10, 20, 30, or $50 \mu \mathrm{g} / \mathrm{ml}$. Two-day-old cultures of P. savastanoi pv. savastanoi strains grown on $\mathrm{KMB}$ agar at $25^{\circ} \mathrm{C}$ were used to prepare aqueous bacterial suspensions that were adjusted to $70 \%$ transmittance (optical density at $600 \mathrm{~nm}$ ) equaling approximately $2 \times 10^{8} \mathrm{CFU} / \mathrm{ml}$ using a spectrophotometer (DU 730; Beckman Coulter, Inc., Indianapolis, IN). Bacterial suspensions were then transferred to copper-amended media in $15-\mathrm{cm}$ Petri dishes by placing a $10-\mu l$ droplet at the edge of the plate and streaking toward the center using a sterile plastic pestle. Eight strains were tested per plate, with two radially opposing replications per strain (16 streaks/plate). Plates were incubated at $25^{\circ} \mathrm{C}$ for 2 days and were then visually assessed for growth in comparison with the controls on nonamended media. Strains that only grew in the presence of MCE of $10 \mu \mathrm{g} / \mathrm{ml}$ were considered copper-sensitive; strains that grew with MCE between 20 and $30 \mu \mathrm{g} / \mathrm{ml}$ were considered moderately sensitive; and strains that had confluent growth with MCE at $50 \mu \mathrm{g} / \mathrm{ml}$ similar to the control plates were considered copper-resistant. Strains that grew with MCE at $50 \mu \mathrm{g} / \mathrm{ml}$ were further challenged on media amended with MCE at $150 \mu \mathrm{g} / \mathrm{ml}$. This assay was done twice for all 147 P. savastanoi pv. savastanoi strains that were obtained.

In vitro baseline sensitivities of $P$. savastanoi pv. savastanoi strains to kasugamycin and oxytetracycline. To evaluate the toxicity of kasugamycin (Kasumin 2L; Arysta LifeScience, Cary, NC) and oxytetracycline (oxytetracycline hydrochloride; Sigma-Aldrich,

Table 1. Origin and copper sensitivity of Pseudomonas savastanoi pv. savastanoi strains from olive knots collected from major olive-producing regions in California

\begin{tabular}{|c|c|c|c|c|c|c|c|}
\hline \multirow[b]{2}{*}{ Number } & \multirow[b]{2}{*}{ Location by county } & \multicolumn{2}{|c|}{ Olive } & \multirow[b]{2}{*}{ Year collected } & \multicolumn{3}{|c|}{$\begin{array}{c}\text { Number of isolates recovered } \\
\text { and copper sensitivity }\end{array}$} \\
\hline & & Cultivar & Type & & $\mathbf{S}$ & MS & $\mathbf{R}$ \\
\hline 1 & Glenn & Koroneiki & Oil & 2011 & 13 & 0 & 0 \\
\hline 2 & Glenn & Manzanillo & Table, oil & 2011 & 7 & 0 & 0 \\
\hline 3 & Yuba & Arbequina & Oil & 2011 & 5 & 0 & 0 \\
\hline 4 & Yuba & Arbosana & Oil & 2011 & 5 & 0 & 0 \\
\hline 5 & Glenn & Manzanillo & Table, oil & 2011 & 6 & 0 & 0 \\
\hline 6 & Glenn & Manzanillo & Table, oil & 2011 & 6 & 0 & 0 \\
\hline 7 & Glenn & Manzanillo & Table, oil & 2011 & 10 & 0 & 0 \\
\hline 8 & Butte & Arbequina & Oil & 2011 & 8 & 0 & 0 \\
\hline 9 & Tulare & Unknown & Table & 2011 & 6 & 0 & 0 \\
\hline 10 & Tehama & Manzanillo & Table, oil & 2011 & 5 & 0 & 0 \\
\hline 11 & Glenn & Manzanillo & Table, oil & 2011 & 2 & 0 & 0 \\
\hline 12 & Tehama & Sevillano & Table & 2011 & 2 & 0 & 0 \\
\hline 13 & Glenn & Arbequina & Oil & 2011 & 7 & 0 & 0 \\
\hline 14 & Glenn & Manzanillo & Table, oil & 2011 & 4 & 0 & 0 \\
\hline 15 & Glenn & Manzanillo & Table, oil & 2011 & 6 & 0 & 0 \\
\hline 16 & Tehama & Manzanillo & Table, oil & 2011 & 5 & 0 & 0 \\
\hline 17 & Tehama & Arbequina & Oil & 2011 & 5 & 0 & 0 \\
\hline 18 & Tehama & Sevillano & Table & 2011 & 4 & 1 & 0 \\
\hline 19 & Glenn & Manzanillo & Table, oil & 2011 & 4 & 0 & 1 \\
\hline 20 & Yuba & Arbosana & Oil & 2012 & 4 & 0 & 0 \\
\hline 21 & Yuba & Arbequina & Oil & 2012 & 2 & 0 & 0 \\
\hline 22 & Yuba & Arbequina & Oil & 2012 & 5 & 0 & 0 \\
\hline 23 & Yuba & Arbequina & Oil & 2012 & 4 & 0 & 0 \\
\hline 24 & Glenn & Manzanillo & Table, oil & 2015 & 9 & 2 & 0 \\
\hline 25 & Glenn & Sevillano & Table & 2015 & 6 & 1 & 2 \\
\hline Total & $\ldots$ & $\ldots$ & $\ldots$ & $\ldots$ & 140 & 4 & 3 \\
\hline
\end{tabular}

${ }^{\mathrm{z}}$ Copper-sensitivity: Sensitive $(\mathrm{S})=$ growth with metallic copper equivalent (MCE) of $<20 \mu \mathrm{g} / \mathrm{ml}$, moderate sensitivity (MS) = growth with MCE of between 20 and $30 \mu \mathrm{g} / \mathrm{ml}$, and resistant $(\mathrm{R})=$ growth with MCE of $150 \mu \mathrm{g} / \mathrm{ml}$. Copper sensitivity was based on two repeat experiments using a total of $147 \mathrm{strains}$. 
St. Louis, MO) against $P$. savastanoi pv. savastanoi, the spiral gradient endpoint method was used (Paton et al. 1990). Aqueous stock suspensions of kasugamycin at $10,000 \mu \mathrm{g} / \mathrm{ml}$ or oxytetracycline at $500 \mu \mathrm{g} / \mathrm{ml}$ were spiraled onto $15-\mathrm{cm}$ Petri dishes containing $50 \mathrm{ml}$ of nutrient agar (Difco Laboratories, Franklin Lakes, NJ) using a spiral plater (Autoplate 4000; Spiral Biotech, Inc., Norwood, MA). Bacterial suspensions were prepared and $10-\mu l$ droplets were streaked radially along the concentration gradient of each bactericide, as described above. After 2 days at $25^{\circ} \mathrm{C}$, inhibition of growth was determined visually and measured at two points: the lowest inhibitory concentration (LIC; point where a reduction of growth is first observed) and the minimum inhibitory concentration (MIC; point where growth is inhibited by $\geq 95 \%$ ). The concentrations at these inhibitory points were determined using the Spiral Gradient Endpoint software (Spiral Biotech) by measuring the distance between the point of inhibition to the center of the plate (radial distance) and entering this measurement into the software. Each isolate was evaluated with two replications per test, and the experiment was performed twice.

Preinfection activity of bactericide treatments against olive knot in field trials. A field trial was performed in an experimental orchard at the University of California (UC) Davis and in a commercial orchard in Yuba County on Arbequina olive trees (Agromillora California, Gridley, CA) in April 2015. For Manzanillo olive (Agromillora California), a study was performed in October 2014 and April 2015 at UC Davis. Trees were planted using a high-density design (Vossen 2007). Wounds were made to 1- to 2-year-old olive twigs approximately 5 to $10 \mathrm{~mm}$ in diameter. Two types of wounds were made, lateral wounds and leaf scar wounds, both simulating mechanical damage that could be incurred from field equipment. For lateral wounds, a small section of the bark ( 10 to $20 \mathrm{~mm}$ long by $5 \mathrm{~mm}$ wide) was removed using a scalpel, exposing the cambial tissue. For leaf scar injuries, leaves were pulled off by hand (Fig. 1A). Each twig represented one experimental replicate, with five internodal lateral wounds and five leaf scar injuries toward the twig tip, and there were eight replications per treatment. Treatments were prepared as aqueous suspensions and applied to wounded twigs until run-off using a hand-held sprayer. Bactericides included kasugamycin (Kasumin 2L) at $200 \mu \mathrm{g} / \mathrm{ml}$, oxytetracycline at $200 \mu \mathrm{g} / \mathrm{ml}$ (Fireline; AgroSource, Inc., Mountainside, NJ), copper hydroxide (Kocide 3000; Du Pont de Nemours and Co., Wilmington, DE; or ChampION ${ }^{++}$; NuFarm Americas, Inc., Alsip, IL) at MCE of 1,260 or 2,520 $\mu \mathrm{g} / \mathrm{ml}$, and a mixture of copper hydroxide (MCE of 1,260 $\mu \mathrm{g} / \mathrm{ml}$ ) and kasugamycin $(200 \mu \mathrm{g} / \mathrm{ml})$. Treatments were allowed to air dry for 1 to $3 \mathrm{~h}$, and twigs were spray inoculated to runoff with $P$. savastano $i$ pv. savastanoi strains 01-26 (copper sensitive) or O1-113 (copper resistant) using an aqueous suspension at $2 \times 10^{7} \mathrm{CFU} / \mathrm{ml}$. Olive trees were evaluated after knots had sufficiently formed on untreatedinoculated wounds (typically 6 months). Treatment efficacy was based on the incidence of disease on lateral wounds and leaf scars as compared with nontreated-inoculated wounds.

Postinfection activity of bactericide treatments against olive knot in field trials. Studies were performed on Arbequina olive, and treatments had five replications per treatment for lateral and leaf scar wounds on 1- to 2-year-old twigs. Wounds were spray inoculated with copper-sensitive $P$. savastanoi pv. savastanoi strain O1-26 $\left(2 \times 10^{7}\right.$ $\mathrm{CFU} / \mathrm{ml}$ ) as described above and treated after selected times with MCE of $1,260 \mu \mathrm{g} / \mathrm{ml}$ (ChampION ${ }^{++}$), kasugamycin (Kasumin 2L) at $200 \mu \mathrm{g} / \mathrm{ml}$, or a mixture of MCE of $1,260 \mu \mathrm{g} / \mathrm{ml}$ with kasugamycin at $200 \mu \mathrm{g} / \mathrm{ml}$. Untreated inoculated wounds were used as positive controls. In studies conducted in spring 2016 and 2017 at UC Riverside and UC Davis, respectively, treatments were done $1,4,8$, or $24 \mathrm{~h}$ after inoculation. In trials done in fall to winter of 2016-17 at both locations, treatments were applied 2, 24, 48, or $96 \mathrm{~h}$ after wound inoculation. Evaluation of disease incidence was performed as described above.

Persistence of protective bactericide treatments against $P$. savastanoi pv. savastanoi. In greenhouse studies, Arbequina olive twigs were wounded and treated with the same bactericides as described above. Treated wounds were spray inoculated with coppersensitive strain $\mathrm{O} 1-26\left(2 \times 10^{7} \mathrm{CFU} / \mathrm{ml}\right)$ using a hand-held sprayer after 72 or $168 \mathrm{~h}$ ( 7 days). Three plants each with two replications (five lateral wounds) of each treatment (a total of six replications) were inoculated after 72 or $168 \mathrm{~h}$. Percent incidence of disease was recorded as the number of knots that developed in lateral wounds. These experiments were repeated once.

Statistical methods and data analysis. For in vitro sensitivity studies, MIC values for kasugamycin and oxytetracycline were plotted in frequency histograms. For this, values were $\log _{10}$-transformed and used to calculate bin widths based on Scott's rule (Scott 1979) with the equation

$$
h=3.49 \hat{\sigma} n^{-\frac{1}{3}}
$$

where $h$ is the bin width, $\hat{\sigma}$ is the sample standard deviation, and $n$ is the sample size.

A pairwise comparison between oxytetracycline and kasugamycin sensitivity was performed to determine whether multiple resistance was present among strains evaluated. Values of kasugamycin were regressed against those of oxytetracycline using ANOVA and regression procedures (SAS version 9.4; SAS Institute Inc., Cary, NC) for all 147 olive knot strains.

All treatments in field and greenhouse studies were arranged in a randomized complete block design. Disease incidence values were arcsine-transformed before statistical analyses using general linear model and least significant difference mean separation procedures (SAS Institute Inc.). Data from repeated studies were combined after Bartlett's test of homogeneity of variance was confirmed.
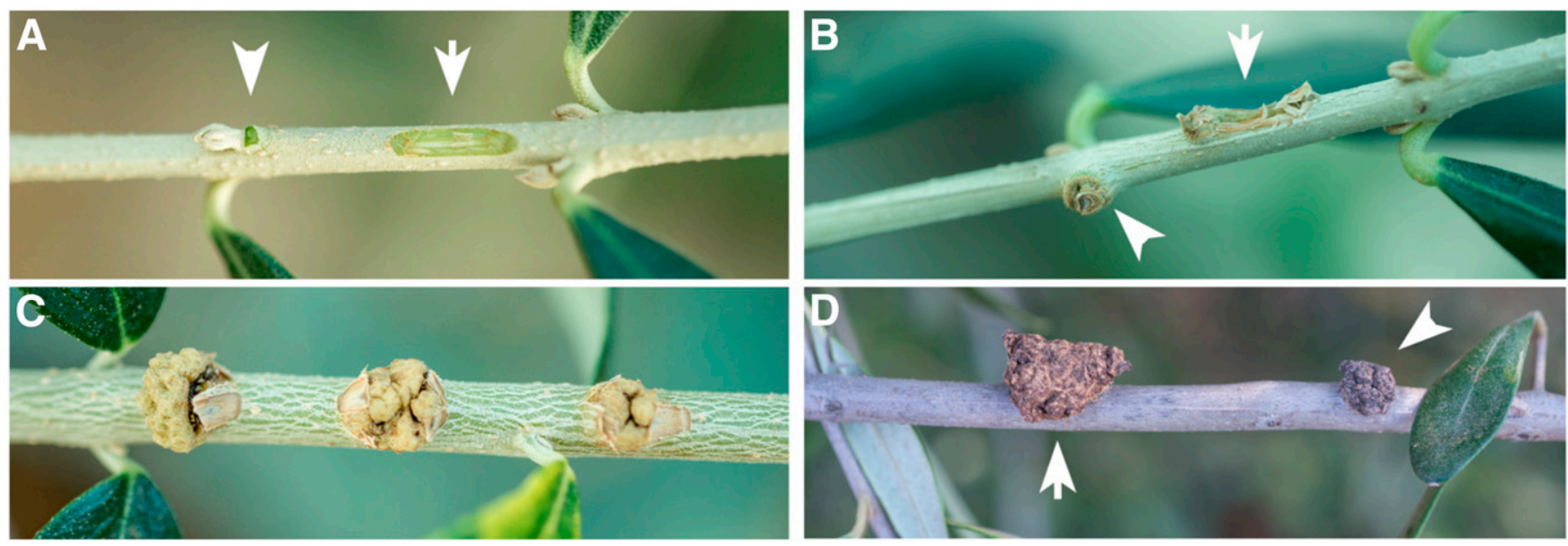

Fig. 1. Knot development on inoculated olive wounds and after natural infections. A, Leaf scar (arrowhead) and lateral (arrow) wounds made on an Arbequina olive twig; B, developing olive knot on leaf scar (arrowhead) and lateral (arrow) wounds; C, knots on lateral wounds 6 months after inoculation; and $\mathbf{D}$, knot forming on naturally occurring leaf scar (arrowhead) and lateral wound (arrow). 


\section{Results}

Laboratory evaluation of copper sensitivity of $P$. savastanoi pv. savastanoi strains. Of the 147 isolates tested, 140 strains $(95.3 \%)$ grew at concentrations of MCE of $\leq 20 \mu \mathrm{g} / \mathrm{ml}, 4$ strains (2.7\%) grew with MCE of between 20 and $30 \mu \mathrm{g} / \mathrm{ml}$ (moderately sensitive), and 3 strains (2\%) grew with MCE of 50 and $150 \mu \mathrm{g} / \mathrm{ml}$ (resistant). The four moderately resistant strains came from three locations in Glenn and Tehama Counties, and the three resistant strains originated from two locations in Glenn County. A summary of the copper sensitivity assays is presented in Table 1 .

In vitro baseline sensitivities of $\boldsymbol{P}$. savastanoi pv. savastanoi strains to kasugamycin and oxytetracycline. For kasugamycin, mean LIC and MIC values were 2.91 and $4.87 \mu \mathrm{g} / \mathrm{ml}$, respectively, whereas those for oxytetracycline were 0.16 and $0.24 \mu \mathrm{g} / \mathrm{ml}$, respectively (Table 2). Scott's distributions of MIC values were unimodal for both bactericides (Fig. 2A and B). No outliers were present beyond $2.8 \times$ the mean for kasugamycin or $1.7 \times$ the mean for oxytetracycline. The model of the

Table 2. Inhibitory concentrations of kasugamycin and oxytetracycline for Pseudomonas savastanoi pv. savastanoi strains from California ${ }^{\mathrm{z}}$

\begin{tabular}{lccllc}
\hline & \multicolumn{2}{c}{ LIC $(\boldsymbol{\mu g} / \mathbf{m l})$} & & \multicolumn{2}{c}{ MIC $(\boldsymbol{\mu g} / \mathbf{m l})$} \\
\cline { 2 - 3 } \cline { 6 - 7 } Bactericide & Range & Mean & & Range & Mean \\
\hline Kasugamycin & 1.20 to 5.87 & 2.91 & & 1.86 to 11.52 & 4.87 \\
Oxytetracycline & 0.09 to 0.23 & 0.16 & & 0.13 to 0.40 & 0.24 \\
\hline
\end{tabular}

${ }^{\mathrm{z}}$ Inhibitory values of bactericides were obtained using the spiral gradient endpoint method on nutrient agar: $\mathrm{LIC}=$ lowest inhibitory concentration where a reduction of growth is first observed and MIC $=$ minimum inhibitory concentration where growth is reduced by $\geq 95 \%$. Values are the average of two experiments, each with two replications. regression of pairwise MIC values for the two bactericides was highly significant $(P<0.0001)$; however, the $R^{2}$ value was 0.3411 (Fig. 3 ).

Preinfection activity of bactericide treatments against olive knot in field trials. Disease developed at high incidence (67.8 to 97.1\%) on untreated lateral and leaf scar wounds of Arbequina and Manzanillo olive trees (Table 3). Approximately 6 months after inoculation, wounds developed typical knots, similar in appearance to those developing naturally (Fig. 1B to D). Oxytetracycline significantly reduced the incidence of disease caused by a copper-sensitive strain on lateral wounds of Arbequina but not of Manzanillo olive. This bactericide also was not effective in reducing the incidence of knots caused by the copper-resistant strain on both olive cultivars (Table 3). Kasugamycin significantly reduced the incidence of disease caused by coppersensitive and -resistant strains on both types of wounds of Arbequina olive. On Manzanillo, this treatment significantly reduced the incidence of disease on lateral wounds but not on leaf scars for sensitive and resistant strains.

The two copper rates were mostly similar in efficacy and significantly reduced knot formation to low incidence on lateral wounds and leaf scars inoculated with the copper-sensitive strain of the pathogen. Using the copper-resistant strain, the high rate of copper was efficacious in most inoculations, except for lateral wounds of Manzanillo (Table 3). The mixture of copper and kasugamycin was highly effective in reducing knots on lateral wounds and leaf scars of Arbequina inoculated with the copper-sensitive strain. It also significantly reduced the disease for the copper-resistant strain, except for the leaf scar inoculations of Manzanillo. This treatment, however, generally did not result in improved efficacy as compared with either rate of copper alone.

Postinfection activity of bactericide treatments against olive knot in field trials. Springtime treatments with copper, kasugamycin,
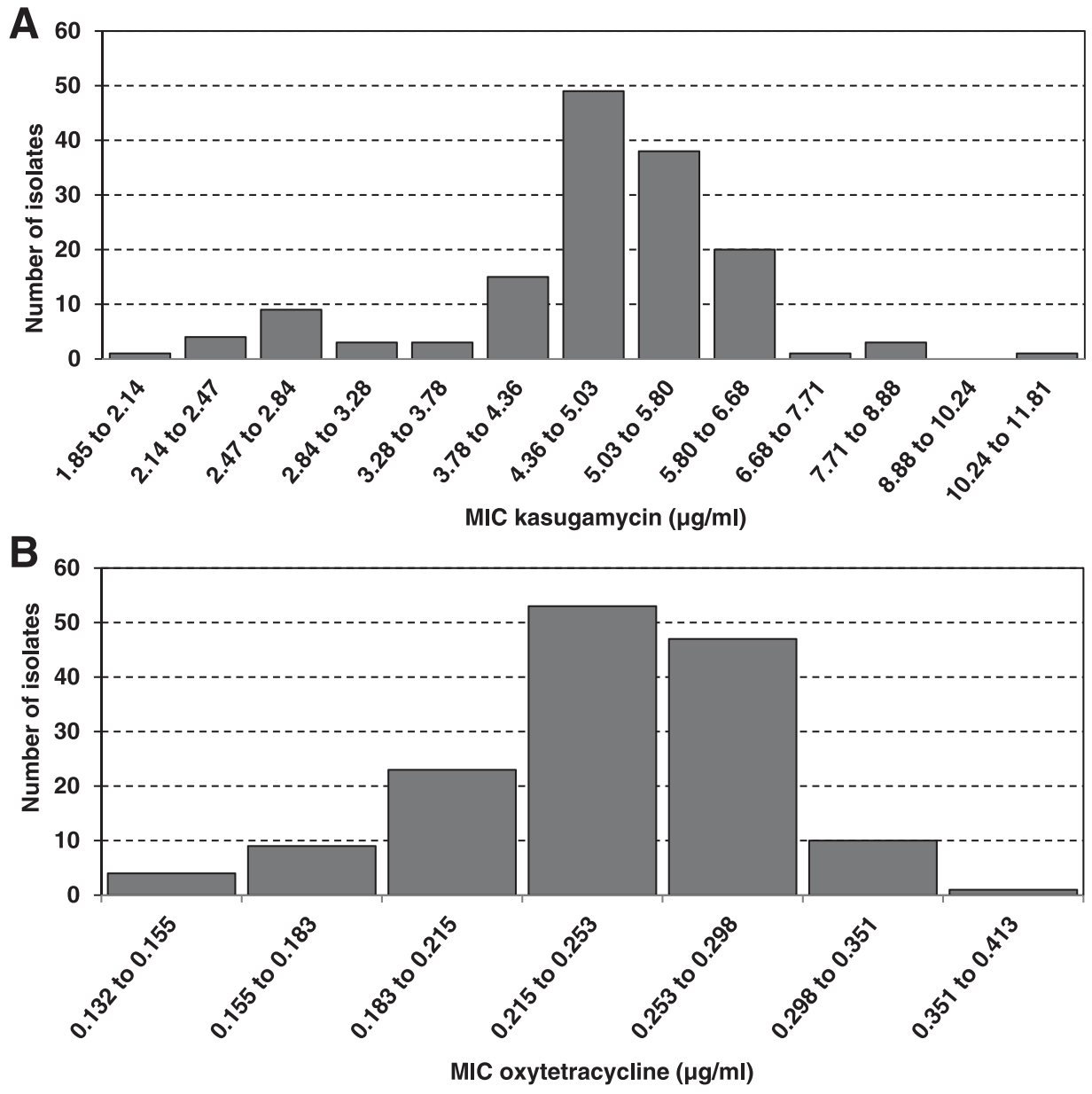

Fig. 2. Scott's distributions of minimum inhibitory concentration (MIC) values (concentrations that inhibit growth by $\geq 95 \%$ ) of 147 Pseudomonas savastanoi pv. savastanoi strains from California for A, kasugamycin, and B, oxytetracycline. Bar height indicates the number of strains within each bin, and bin width was calculated using Scott's method (Scott 1979). 
or the mixture to both types of wounds within $24 \mathrm{~h}$ after inoculation all significantly reduced the incidence of disease from that of the untreated control (Table 4). On lateral wounds, disease was mostly reduced to low levels, except for kasugamycin at the 24-h timing, and no disease

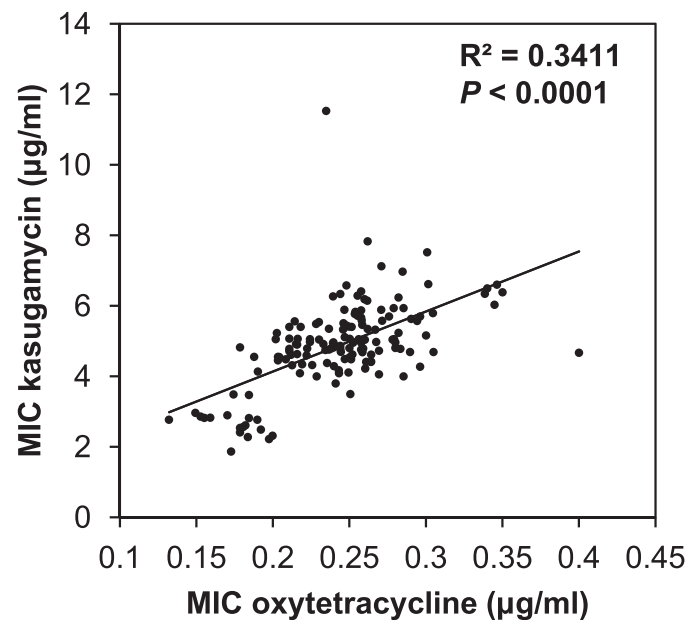

Fig. 3. Scatter plot of minimum inhibitory concentration (MIC) values (concentrations that inhibit growth by $\geq 95 \%$ ) of kasugamycin plotted against those of oxytetracycline for 147 Pseudomonas savastanoi pv. savastanoi strains. developed in the mixture treatment applied 1,4 , or $24 \mathrm{~h}$ after inoculation. On leaf scar wounds, none of the treatments resulted in zero levels of disease. In general, the 24-h timing had the highest level of disease for each bactericide treatment (Table 4).

The efficacy of fall or winter applications of bactericides at selected times within $24 \mathrm{~h}$ after inoculation to leaf scars wounds on Arbequina olive (Table 5) was generally lower than those applied in the spring experiments (Table 4), and the 48- or 96-h treatments were often statistically similar to the $24-\mathrm{h}$ treatments. Most timings of copper or the mixture treatments to lateral wounds in experiment 1 that was conducted in the fall resulted in significantly less knot formation than in the untreated control. For kasugamycin, however, only the 2- and 96-h application timings had significantly less disease than the untreated control. The mixture treatment in this experiment had some of the lowest incidence values on lateral wounds for all timings but there was no significant difference as compared with most of the copper treatments. In contrast, in experiment 2 that was done in the winter, all treatments significantly reduced knot formation to low or zero levels as compared with the untreated control, even when applied $96 \mathrm{~h}$ after inoculation (Table 5).

In both fall and winter experiments, none of the treatment timings was highly effective in preventing knot formation on leaf scar wounds (Table 5). The 2-h timings were mostly more effective than the later timings in experiment 1 . Additionally, kasugamycin and the copper-kasugamycin mixture were significantly more effective than copper by itself in the winter treatments of experiment 2 .

Table 3. Efficacy of bactericides as preinfection wound treatments for reducing the incidence of knot formation after inoculation with copper-sensitive or -resistant Pseudomonas savastanoi pv. savastanoi strains in field trials on two olive cultivars

\begin{tabular}{|c|c|c|c|c|c|c|c|c|c|}
\hline \multirow[b]{4}{*}{ Treatment $^{\mathrm{z}}$} & \multirow[b]{4}{*}{ Rate $(\mu \mathrm{g} / \mathrm{ml})$} & \multicolumn{8}{|c|}{ Mean incidence of knots on treated-inoculated wounds $(\%)^{y}$} \\
\hline & & \multicolumn{4}{|c|}{ Arbequina } & \multicolumn{4}{|c|}{ Manzanillo } \\
\hline & & \multicolumn{2}{|c|}{$\mathrm{Cu}^{\mathrm{s}}$} & \multicolumn{2}{|c|}{$\mathrm{Cu}^{\mathrm{R}}$} & \multicolumn{2}{|c|}{$\mathrm{Cu}^{\mathrm{S}}$} & \multicolumn{2}{|c|}{$\mathrm{Cu}^{\mathrm{R}}$} \\
\hline & & LW & LS & LW & LS & $\mathbf{L W}$ & $\mathbf{L S}$ & LW & LS \\
\hline Nontreated control & 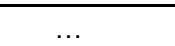 & $85.7 \mathrm{a}$ & $81.1 \mathrm{a}$ & $80.0 \mathrm{a}$ & $67.8 \mathrm{a}$ & $84.6 \mathrm{a}$ & $77.1 \mathrm{a}$ & $97.1 \mathrm{a}$ & $76.3 \mathrm{ab}$ \\
\hline Oxytetracycline & 200 & $58.6 \mathrm{~b}$ & $57.8 \mathrm{~b}$ & $57.3 \mathrm{ab}$ & $51.8 \mathrm{ab}$ & $80 \mathrm{a}$ & $62.8 \mathrm{a}$ & $94.2 \mathrm{ab}$ & $65.4 \mathrm{ab}$ \\
\hline Kasugamycin & 200 & $12.9 \mathrm{c}$ & $53.3 \mathrm{~b}$ & $20.0 \mathrm{~d}$ & $38.9 \mathrm{~b}$ & $15.3 \mathrm{~b}$ & $72.8 \mathrm{a}$ & $42.8 \mathrm{c}$ & $85.4 \mathrm{ab}$ \\
\hline Copper hydroxide & 1,260 & $2.9 \mathrm{~d}$ & $12.5 \mathrm{c}$ & $38.6 \mathrm{bcd}$ & $47.5 \mathrm{ab}$ & $29.2 \mathrm{~b}$ & $27.1 \mathrm{~b}$ & $97.1 \mathrm{a}$ & $76.3 \mathrm{ab}$ \\
\hline Copper hydroxide & 2,520 & $4.3 \mathrm{~cd}$ & $5.6 \mathrm{c}$ & $38.8 \mathrm{bc}$ & $26.7 \mathrm{~b}$ & $12.3 \mathrm{~b}$ & $4.2 \mathrm{c}$ & $91.4 \mathrm{ab}$ & $66.0 \mathrm{~b}$ \\
\hline Copper + kasugamycin & $1,260+200$ & $2.9 \mathrm{~d}$ & $11.1 \mathrm{c}$ & $36.0 \mathrm{~cd}$ & $42.4 \mathrm{ab}$ & $21.5 \mathrm{~b}$ & $18.5 \mathrm{bc}$ & $82.8 \mathrm{~b}$ & $85.4 \mathrm{a}$ \\
\hline
\end{tabular}

${ }^{y}$ Experiments were conducted in the spring on Arbequina and in the spring and fall seasons on Manzanillo olive. Inoculum $\left(2 \times 10^{7} \mathrm{CFU} / \mathrm{ml}\right)$ consisted of a copper-sensitive $\left(\mathrm{Cu}^{\mathrm{S}}\right)$ or a copper-resistant $\left(\mathrm{Cu}^{\mathrm{R}}\right)$ strain of $P$. savastanoi pv. savastanoi. $\mathrm{LW}=$ lateral wounds and $\mathrm{LS}=$ leaf scars. Data are the average of two experiments after testing for homogeneity of variance using Bartlett's test. Values followed by the same letter within each column are not significantly different based on general linear model and least significant difference tests $(P<0.05)$.

${ }^{\mathrm{z}}$ For the copper hydroxide treatments at the low rate, Kocide 3000 was used whereas, for the high rate, ChampION ${ }^{++}$was used. Rates are expressed as metallic copper equivalent.

Table 4. Efficacy of springtime bactericide treatments applied at selected times within $24 \mathrm{~h}$ after inoculation to wounds for reducing the incidence of knot formation on Arbequina olive

\begin{tabular}{|c|c|c|c|c|}
\hline \multirow[b]{2}{*}{ Treatment $^{\mathrm{z}}$} & \multirow[b]{2}{*}{ Rate $(\mu \mathrm{g} / \mathrm{ml})$} & \multirow[b]{2}{*}{ Timing (h) } & \multicolumn{2}{|c|}{ Incidence of knots on inoculated wounds (\%)y } \\
\hline & & & Lateral wounds & Leaf scars \\
\hline Untreated control & & $\ldots$ & $80.0 \mathrm{a}$ & $71.4 \mathrm{a}$ \\
\hline \multirow[t]{4}{*}{ Copper } & 1,260 & 1 & $2.0 \mathrm{c}$ & $18.6 \mathrm{bcd}$ \\
\hline & $\ldots$ & 4 & $4.0 \mathrm{c}$ & $17.1 \mathrm{bcd}$ \\
\hline & $\ldots$ & 8 & $4.0 \mathrm{c}$ & $25.7 \mathrm{bc}$ \\
\hline & $\ldots$ & 24 & $4.0 \mathrm{c}$ & $30.0 \mathrm{~b}$ \\
\hline \multirow[t]{4}{*}{ Kasugamycin } & 200 & 1 & $6.0 \mathrm{c}$ & $20 \mathrm{bcd}$ \\
\hline & $\ldots$ & 4 & $8.0 \mathrm{c}$ & $10 \mathrm{~cd}$ \\
\hline & $\ldots$ & 8 & $6.0 \mathrm{c}$ & $17.1 \mathrm{bcd}$ \\
\hline & $\ldots$ & 24 & $27.0 \mathrm{~b}$ & $27.7 \mathrm{bc}$ \\
\hline \multirow[t]{4}{*}{ Copper + kasugamycin } & $1,260+200$ & 1 & $0.0 \mathrm{c}$ & $15.7 \mathrm{bcd}$ \\
\hline & $\ldots$ & 4 & $0.0 \mathrm{c}$ & $10.8 \mathrm{~d}$ \\
\hline & $\ldots$ & 8 & $4.0 \mathrm{c}$ & $10.8 \mathrm{~cd}$ \\
\hline & $\ldots$ & 24 & $0.0 \mathrm{c}$ & $33.3 \mathrm{~b}$ \\
\hline
\end{tabular}

${ }^{\mathrm{y}}$ Lateral and leaf scar wounds were inoculated with a copper-sensitive Pseudomonas savastanoi pv. savastanoi strain and treated after selected timings in March or April 2017. Data are the average of two experiments based on homogeneity of variance using Bartlett's test. Values followed by the same letter within each column are not significantly different based on general linear model and least significant difference tests $(P<0.05)$.

${ }^{\mathrm{z}}$ Copper hydroxide $\left(\mathrm{ChampION}^{++}\right)$was used for the copper treatments. For treatments containing copper, rates are expressed as metallic copper equivalent. 
Persistence of bactericide treatments on wounds for preventing infection by $P$. savastanoi pv. savastanoi. In greenhouse studies, copper and copper-kasugamycin applied 3 or 7 days before inoculation reduced disease incidence by $\geq 50 \%$ (Table 6). Kasugamycin treatments did not significantly reduce knot formation at both inoculation timings.

\section{Discussion}

Our survey of $P$. savastanoi pv. savastanoi strains from California showed differential degrees of sensitivity to copper but most strains were considered sensitive. Copper resistance is considered a qualitative trait in the ability of Pseudomonas spp. to grow on media amended with MCE of approximately $50 \mu \mathrm{g} / \mathrm{ml}$ (Andersen et al. 1991; Cazorla et al. 2002) and, in previous studies, resistance was not found in evaluations of more than 550 strains of the olive knot pathogen in Spain (Quesada et al. 2010). Although copper-resistant strains of $P$. savastanoi pv. savastanoi were previously reported from California, these strains were nonpathogenic when inoculated to olive (Teviotdale and Krueger 1998) and were not well characterized using more stringent identification methods. In our studies, initial isolations from olive knots often resulted in recovery of fluorescent pseudomonads that were copper resistant but iaaL was not successfully amplified using the IAAL primers (Penyalver et al. 2000), and these strains were nonpathogenic to olive. Our $P$. savastanoi pv. savastanoi strains, including the three highly copper-resistant ones (growth with MCE at $150 \mu \mathrm{g} / \mathrm{ml}$ ) that we recovered from commercial Sevillano and Manzanillo olive groves in northern California were identified based on their growth on a semiselective medium, amplification of the iaaL gene, and fulfilling Koch's postulates. Therefore, to our knowledge, this is the first report of copper-resistant, pathogenic strains of $P$. savastanoi pv. savastanoi from olive in California and elsewhere.

Development of copper resistance was likely a result of repeated exposure of the pathogen to copper sprays that have been used in California for over a century to control fungal and bacterial diseases of olive (Horne et al. 1912; Wilson 1935). In our field studies, copper treatments at registered rates were highly effective in reducing knot development on two olive cultivars when inoculated with a coppersensitive strain of the pathogen. Higher registered rates were often more effective in reducing disease incidence. However, when copper-treated olive wounds were inoculated with a copper-resistant strain, disease control was significantly reduced even when using the maximum labeled copper rate, especially on Manzanillo olive. Although the copperresistant strains only represented $2 \%$ of the total isolates collected, continual usage of copper alone will likely increase the incidence of such strains, making the development of new bactericidal treatments and copper-enhancing-materials critical for resistance management and disease control.
Kasugamycin was identified as an effective alternative treatment, and it was the best treatment on lateral wounds inoculated with a copperresistant strain. Interestingly, kasugamycin was less effective on leaf scars in some experiments, suggesting that the type of wound treated can have a major effect on disease control. Furthermore, as for the copper treatments, disease reduction by kasugamycin was often lower on Manzanillo than on Arbequina olive, suggesting that olive cultivar may affect the performance of the bactericide treatment. Mixtures of copper and kasugamycin mostly did not improve disease control compared with using copper by itself; however, this mixture treatment with two ingredients active against the pathogen will help to reduce resistance development against either compound.

In vitro tests demonstrated that oxytetracycline and kasugamycin were toxic to $P$. savastanoi pv. savastanoi; however, oxytetracycline was more toxic based on lower MIC values. Distributions of sensitivity values were unimodal, and no strains resistant to either bactericide were identified. No cross-resistance was observed when the inhibitory values of oxytetracycline were compared with those of kasugamycin for the 147 strains because the coefficient of correlation was very low $\left(R^{2}=0.3411\right)$. This was an expected result because the two bactericides do not share the same modes of action (Copping and Duke 2007). Still, oxytetracycline did not perform consistently in field trials and, in most cases, showed a low efficacy when compared with copper or kasugamycin treatments.

Table 6. Persistence of bactericides applied to lateral twig wounds of Arbequina olive to prevent knot formation by Pseudomonas savastanoi pv. savastanoi in greenhouse studies

\begin{tabular}{lclc}
\hline & & \multicolumn{2}{c}{$\begin{array}{c}\text { Incidence of knot } \\
\text { formation }(\boldsymbol{\%}) \mathbf{y}^{\mathbf{y}}\end{array}$} \\
\cline { 3 - 4 } & & $\begin{array}{c}\text { Inoculation timing } \\
\text { after treatment }\end{array}$ \\
\cline { 3 - 4 } Treatment $^{\mathbf{z}}$ & Rate $(\boldsymbol{\mu g} / \mathbf{m l})$ & $\mathbf{3}$ days & $\mathbf{7 ~ d a y s}$ \\
\hline Untreated control $_{\text {Copper }}$ & $\ldots$ & $80 \mathrm{a}$ & $81.8 \mathrm{a}$ \\
Kasugamycin & 1,260 & $40 \mathrm{bc}$ & $34.5 \mathrm{~b}$ \\
Copper + kasugamycin & $1,260+200$ & $74.4 \mathrm{ab}$ & $90 \mathrm{a}$ \\
\hline
\end{tabular}

${ }^{y}$ Lateral wounds were treated and inoculated with a copper-sensitive $P$. savastanoi pv. savastanoi strain after 3 or 7 days. Data are the average of two experiments after testing for homogeneity of variance using Bartlett's test. Values followed by the same letter within each column are not significantly different based on general linear model and least significant difference tests $(P<0.05)$.

${ }^{\mathrm{z}}$ Copper hydroxide (Kocide 3000) was used for the copper treatments. For treatments containing copper, rates are expressed as metallic copper equivalent.

Table 5. Efficacy of fall and winter bactericide treatments applied at selected times within $96 \mathrm{~h}$ after inoculation to wounds for reducing the incidence of knot formation of Arbequina olive

\begin{tabular}{|c|c|c|c|c|c|c|}
\hline \multirow[b]{3}{*}{ Treatment $^{\mathrm{z}}$} & \multirow[b]{3}{*}{ Rate $(\mu \mathrm{g} / \mathrm{ml})$} & \multirow[b]{3}{*}{ Timing (h) } & \multicolumn{4}{|c|}{ Incidence of knots on inoculated wounds $(\%)^{y}$} \\
\hline & & & \multicolumn{2}{|c|}{ Experiment 1} & \multicolumn{2}{|c|}{ Experiment 2} \\
\hline & & & Lateral wounds & $\overline{\text { Leaf scars }}$ & Lateral wounds & Leaf scars \\
\hline Untreated control & & & $93.3 \mathrm{a}$ & $90 \mathrm{a}$ & $94.2 \mathrm{a}$ & $96 \mathrm{a}$ \\
\hline \multirow[t]{4}{*}{ Copper } & 1,260 & 2 & $28.5 \mathrm{def}$ & $60.7 \mathrm{~cd}$ & $0 \mathrm{c}$ & $86 \mathrm{a}$ \\
\hline & $\ldots$ & 24 & 46.8 b-f & $87.5 \mathrm{ab}$ & $0 \mathrm{c}$ & $88 \mathrm{a}$ \\
\hline & $\ldots$ & 48 & $50 \mathrm{~b}-\mathrm{e}$ & $85.6 \mathrm{ab}$ & $0 \mathrm{c}$ & $82 \mathrm{a}$ \\
\hline & $\ldots$ & 96 & $35.7 \mathrm{c}-\mathrm{f}$ & $89.2 \mathrm{a}$ & $0 \mathrm{c}$ & $90 \mathrm{a}$ \\
\hline \multirow[t]{4}{*}{ Kasugamycin } & 200 & 2 & $31.4 \mathrm{def}$ & $37.1 \mathrm{~d}$ & $0 \mathrm{c}$ & $26 \mathrm{bc}$ \\
\hline & $\ldots$ & 24 & $78.5 \mathrm{ab}$ & $75 a b c$ & $2.8 \mathrm{c}$ & $30 \mathrm{bc}$ \\
\hline & $\ldots$ & 48 & $67.8 \mathrm{abc}$ & $85.7 \mathrm{ab}$ & $14.2 \mathrm{~b}$ & $40 \mathrm{bc}$ \\
\hline & $\ldots$ & 96 & $57.1 \mathrm{bcd}$ & $75 \mathrm{abc}$ & $2.8 \mathrm{c}$ & $42 \mathrm{~b}$ \\
\hline \multirow[t]{4}{*}{ Copper + kasugamycin } & $1,260+200$ & 2 & $15.6 \mathrm{f}$ & $34.3 \mathrm{~d}$ & $0 \mathrm{c}$ & $18 \mathrm{c}$ \\
\hline & $\ldots$ & 24 & $17.8 \mathrm{ef}$ & $67.8 \mathrm{bc}$ & $0 \mathrm{c}$ & $32 \mathrm{bc}$ \\
\hline & $\ldots$ & 48 & $39.2 \mathrm{c}-\mathrm{f}$ & $75 a b c$ & $0 \mathrm{c}$ & $34 \mathrm{bc}$ \\
\hline & $\ldots$ & 96 & $43.8 \mathrm{c}-\mathrm{f}$ & $78.1 \mathrm{abc}$ & $0 \mathrm{c}$ & $28 \mathrm{bc}$ \\
\hline
\end{tabular}

y Lateral and leaf scar wounds were inoculated with a copper-sensitive Pseudomonas savastanoi pv. savastanoi strain and treated after selected timings in September 2016 (experiment 1) or January 2017 (experiment 2). Values followed by the same letter within each column are not significantly different based on general linear model and least significant difference tests $(P<0.05)$.

${ }^{\mathrm{z}}$ Copper hydroxide $\left(\mathrm{ChampION}^{++}\right)$was used for the copper treatments. For treatments containing copper, rates are expressed as metallic copper equivalent. 
Oxytetracycline is considered to be sensitive to ultraviolet radiation found naturally in sunlight, and this was suggested to be a contributing factor to the rapid degradation of the bactericide (Christiano et al. 2010). Unfortunately, the same researchers showed that the addition of several UV protectants to oxytetracycline treatments was not adequate for maintaining effective concentrations against Xanthomonas arboricola pv. pruni on peach leaves. Still, oxytetracycline has potential for treating olive knot if the negative effects of sunlight can be controlled.

In addition to the direct biocidal activity of treatments, application timing is critical in determining disease control. Our field studies indicated that copper, kasugamycin, and mixtures of copper and kasugamycin applied $24 \mathrm{~h}$ or more after inoculation were sometimes less effective than treatments applied earlier. The efficacy of postinfection treatments within this time period varied widely among studies conducted during different times of the year; however, in several trials, earlier applications resulted in significantly lower disease. Treatments in the springtime were generally more effective than those applied in fall or winter. Copper is known as a contact bactericide with no curative properties. Applications at or shortly after inoculation of wounds during favorable environmental conditions such as rainfall are critical to inhibit bacterial colonization before infections are established. Therefore, it is essential that olive trees are treated as soon as possible after harvest and at other times when large numbers of new injuries occur (e.g., hail storms or natural leaf drop) and rainfall events are likely under California conditions.

Previous research revealed that oxytetracycline was not likely taken up by plant leaves when applied externally and only moved systemically if delivered through injection (Christiano et al. 2010). Kasugamycin is characterized as a systemic compound on certain crops (Copping and Duke 2007; Lu et al. 2012), although we found its effectiveness reduced when applied to lateral wounds of olive that were inoculated several days in advance, suggesting that it was not readily absorbed by olive tissue or was diluted to sublethal concentrations by movement into the wounds that prevented disease control. It was also less effective on leaf scar wounds (treated before or after inoculation) than on lateral wounds.

The persistence of treatments is another important factor when considering disease prevention. In greenhouse studies, the residual activity of copper and copper-kasugamycin on olive injuries lasted for at least a week, and inoculations of treated wounds resulted in fewer knots than those of untreated wounds. Wounds inoculated after 7 days show reduced susceptibility compared with those inoculated earlier (K. A. Nguyen, unpublished). Thus, wound healing contributes to preventing infections. Hewitt (1938) showed that wound healing responses are initiated on olive leaf scars within days after leaf drop, preventing most pathogen infections from occurring.

This research presents strong evidence that kasugamycin can be similarly effective as copper in reducing olive knot while providing a different mode of action for disease control. Integration of copper and kasugamycin in mixtures or rotations has the potential to reduce the risk of resistance developing to either bactericide, enabling the prolonged effective use of both compounds. Oxytetracycline was moderately effective in selected studies, and disease control was inconsistent. Future work on optimizing its performance will be necessary to support its use for the control of olive knot.

\section{Acknowledgments}

We thank E. Fichtner, D. Lightle, and W. Krueger (University of California Cooperative Extension for Tulare, Butte/Glenn, and Glenn Counties, respectively) for collecting diseased olive samples.

\section{Literature Cited}

Adaskaveg, J. E., Förster, H., and Wade, M. L. 2011. Effectiveness of kasugamycin against Erwinia amylovora and its potential use for managing fire blight of pear. Plant Dis. 95:448-454.

Adaskaveg, J. E., and Hine, R. B. 1985. Copper tolerance and zinc sensitivity of Mexican strains of Xanthomonas campestris pv. vesicatoria, causal agent of bacterial spot of pepper. Plant Dis. 69:993-996.

Andersen, G. L., Menkissoglou, O., and Lindow, S. E. 1991. Occurrence and properties of copper-tolerant strains of Pseudomonas syringae isolated from fruit trees in California. Phytopathology 81:648-656.
Cazorla, F. M., Arrebola, E., Sesma, A., Pérez-García, A., Codina, J. C., Murillo, J. and de Vicente, A. 2002. Copper resistance in Pseudomonas syringae strains isolated from mango is encoded mainly by plasmids. Phytopathology 92:909-916.

Christiano, R. S. C., Reilly, C. C., Miller, W. P., and Scherm, H. 2010. Oxytetracycline dynamics on peach leaves in relation to temperature, sunlight, and simulated rain. Plant Dis. 94:1213-1218.

Comai, L., and Kosuge, T. 1980. Involvement of plasmid deoxyribonucleic acid in indoleacetic acid synthesis in Pseudomonas savastanoi. J. Bacteriol. 143:950-957.

Comai, L., and Kosuge, T. 1982. Cloning and characterization of iaaM, a virulence determinant of Pseudomonas savastanoi. J. Bacteriol. 149:40-46.

Copping, L. G., and Duke, S. O. 2007. Natural products that have been used commercially as crop protection agents. Pest Manage. Sci. 63:524-554.

Ercolani, G. L. 1978. Pseudomonas savastanoi and other bacteria colonizing the surface of olive leaves in the field. J. Gen. Microbiol. 109:245-257.

Gardan, L., Bollet, C., Abu Ghorrah, M., Grimont, F., and Grimont, P. A. D. 1992 DNA relatedness among the pathovar strains of Pseudomonas syringae subsp. savastanoi Janse (1982) and proposal of Pseudomonas savastanoi sp. nov. Int. J. Syst. Bacteriol. 42:606-612.

Hewitt, W. 1938. Leaf-scar infection in relation to the olive-knot disease. Hilgardia 12:39-71

Horne, T., Parker, B., and Daines, L. L. 1912. The method of spreading of the olive knot disease. Phytopathology 2:101-105.

King, E. O., Ward, M. K., and Raney, D. E. 1954. Two simple media for the demonstration of pyocyanin and fluorescein. J. Lab. Clin. Med. 44:301-307.

Lu, L., Zhao, S., and Deng, L. 2012. Residues and dynamics of kasugamycin in chili and soil. Bull. Environ. Contam. Toxicol. 89:649-653.

Marco, G. M., and Stall, R. E. 1983. Control of bacterial spot of pepper initiated by strains of Xanthomonas campestris pv. vesicatoria that differ in sensitivity to copper. Plant Dis. 67:779-781.

McGhee, G. C., and Sundin, G. W. 2011. Evaluation of kasugamycin for fire blight management, effect on nontarget bacteria, and assessment of kasugamycin resistance potential in Erwinia amylovora. Phytopathology 101:192-204.

Nguyen, K. A., Förster, H., and Adaskaveg, J. E. 2017. Quaternary ammonium compounds as new sanitizers for reducing the spread of the olive knot pathogen on orchard equipment. Plant Dis. 101:1188-1193.

Okuyama, A., Machiyama, N., Kinoshita, T., and Tanaka, N. 1971. Inhibition by kasugamycin of initiation complex formation on $30 \mathrm{~S}$ ribosomes. Biochem. Biophys. Res. Commun. 43:196-199.

Paton, J. H., Holt, H. A., and Bywater, M. J. 1990. Measurement of MICs of antibacterial agents by spiral gradient endpoint compared with conventional dilution method. Int. J. Exp. Clin. Chemother. 3:31-38.

Penyalver, R., Garcia, A., Ferrer, A., Bertolini, E., and Lopez, M. M. 2000. Detection of Pseudomonas savastanoi pv. savastanoi in olive plants by enrichment and PCR Appl. Environ. Microbiol. 66:2673-2677.

Quesada, J. M., Penyalver, R., Pérez-Panadés, J., Salcedo, C. I., Carbonell, E. A., and López, M. M. 2010. Comparison of chemical treatments for reducing epiphytic Pseudomonas savastanoi pv. savastanoi populations and for improving subsequent control of olive knot disease. Crop Prot. 29:1413-1420.

Schroth, M. N., and Hildebrand, D. C. 1968. A chemotherapeutic treatment for selectively eradicating crown gall and olive knot neoplasms. Phytopathology 58:848-854.

Schroth, M. N., Hildebrand, D. C., and O'Reilly, H. J. 1968. Off-flavor of olives from trees with olive knot tumors. Phytopathology 58:524-525.

Schroth, M. N., Osgood, J. W., and Miller, T. D. 1973. Quantitative assessment of the effect of the olive knot disease on olive yield and quality. Phytopathology 63:1064-1065.

Scott, D. W. 1979. On optimal and data-based histograms. Biometrika 66:605-610.

Sibbett, G. S., and Ferguson, L. 2005. Olive Production Manual, 2nd ed. Univ. Calif. Agric. Nat. Res. Publ. 3353, Richmond, CA.

Surico, G., Iacobellis, N. S., and Sisto, A. 1985. Studies on the role of indole3 -acetic acid and cytokinins in the formation of knots on olive and oleander plants by Pseudomonas syringae pv. savastanoi. Physiol. Plant Pathol. 26:309-320.

Surico, G., and Lavermicocca, P. 1989. A semiselective medium for the isolation of Pseudomonas syringae pv. savastanoi. Phytopathology 79:185-190.

Tanaka, N., Yamaguchi, H., and Umezawa, H. 1966. Mechanism of kasugamycin action on polypeptide synthesis. J. Biochem. 60:429-434.

Teviotdale, B. L., and Krueger, B. 1998. Olive knot control assessment of copper resistance in Pseudomonas savastanoi. KAC Plant Prot. Q. 8:1-4.

Teviotdale, B. L., and Krueger, W. H. 2004. Effects of timing of copper sprays, defoliation, rainfall, and inoculum concentration on incidence of olive knot disease. Plant Dis. 88:131-135.

Tous, J., Romero, A., and Hermoso, J. F. 2010. New trends in olive orchard design for continuous mechanical harvesting. Adv. Hortic. Sci. 24:43-52.

Umezawa, H., Okami, Y., Hashimoto, T., Suhara, Y., Hamada, M., and Takeuchi, T. J. 1965. A new antibiotic, kasugamycin. J. Antibiot. Ser. A 18:101-103.

Vossen, P. 2007. Olive oil: History, production, and characteristics of the world's classic oils. HortScience 42:1093-1100.

Wilson, E. E. 1935. The olive knot disease: Its inception, development and control Hilgardia 9:2331-264.

Young, J. M. 2004. Olive knot and its pathogens. Australas. Plant Pathol. 33:33-39.

Zevenhuizen, L. P. T. M., Dolfing, J., Eshuis, E. J., and Scholten-Koerselman, I. J 1979. Inhibitory effects of copper on bacteria related to the free ion concentration. Microb. Ecol. 5:139-146. 